\title{
MECHANICAL PROPERTIES OF SURFACE STRENGTHENED MATERIALS AND DESIGNING OF SURFACE LAYERS
}

\author{
Z. HAŚ
}

Łódź Technical University, Stefanowskiego 1, 90-924 Eódź, Poland

AND A. NAKONIECZNY

Institute of Precision Mechanics, Duchnicka 3, 00-967 Warszawa, Poland

Technological surface layers, most often met in practice, received by the methods of heat, thermo-diffusion, mechanical and chemical treatment have been described. The range of application of surface layers received as a result of various technological treatments have been presented. Improvement of mechanical properties of the machine elements and constructions after surface treatment is the subject of this paper. The changes of mechanical, static and fatigue properties as well as impact strength, crack resistance and friction properties, such as wear resistance, seizing resistance and friction factor have been discussed. It has been found that the efficiency of the improvement of mechanical properties is a function of technological parameters and of a type of destruction being a result of the mechanical external loads. We claim that it is possible to design surface layers in dependence on the parameters of processing, or on the structure of the layers (determined by hardening, residual stresses) and on the mechanical external loads of machine parts and constructions. Methods of designing surface layers, useful in practice, have been presented. Examples of changes of the mechanical properties after surface treatment have been given.

PACS numbers: $68.35 . \mathrm{Gy}{ }^{\prime}, 68.45 . \mathrm{Nj}$,

\section{The general characteristic of surface layers}

The analysis of the mechanical properties - static and dynamic - as well as the tribological ones and the kinds of destruction of machine parts and constructions after surface treatment, connected with these properties, allows to say that important features of strength relation between surface layer and core are:

- features of surface layers at a layer cross-section,

- features of interface zone between surface layer and core. 
The below mentioned features of surface layers are very important:

- gradient of elements' concentration in a layer,

- changes of the type of atomic lattice,

- phase changes,

- gradient of defects of structure being a result of plastic strains - dislocation, texture, shape and size of grains,

- gradients of mechanical properties (hardness, residual stresses),

- gradients of mechanical properties (of strength and tribological ones) [1].

Considering the above criteria the following kinds of surface layers can be distinguished:

1. Layers without phase transition.

These layers occur as a result of strain hardening - without gradient of elements' concentration, without change of the type of atomic lattice and phase boundary, but with gradients of mechanical properties and defects of structure.

2. Layers with phase transition.

These layers appear after surface thermal treatment - without gradient of elements' concentration, without change of the type of atomic lattice and distinct phase boundary, but with the mechanical properties gradient and the distinct changes of structure.

3. Diffusion solution layers.

These layers occur as a result of thermo-chemical treatment (carburizing) - with carbon concentration gradient, changes of structure in cross-section and changes of the mechanical properties, without distinct phase boundary and change of atomic lattice (except of just under-surface zone of the austenite-martensite structure).

4. Diffusion layers with structure of nitride phase and solution.

These layers occur as a result of thermo-chemical treatment e.g. nitriding with change of atomic lattice and distinct phase point in the layer, with change of nitrogen concentration gradient and with the changes of structure and the mechanical properties gradient. The abrupt changes between nitride phase and solution as well as the continuous change of the mechanical properties between layer and core are very characteristic of such layer.

5. Diffusion layers with structure of carbide phase and solution.

These layers occur as a result of chrome hardening or titanizing with change of the type of lattice between carbide phase and solution, with distinct phase boundary, with elements' concentration gradient and the abrupt changes of structure and the mechanical properties between carbide phase and solution.

6. Adhesive layers of one metal.

These layers occur as a result of galvanic processes, without elements' concentration gradient, without mechanical properties gradient, without change of kind of atomic lattice and without change of structure, but with distinct phase point and the abrupt change of the mechanical properties between layer and core. 


\section{Adhesive layers of a few elements.}

These layers, obtained by the PVD (physical vapour deposition) techniques, are characterised by elements' concentration gradients in layers, changes of structure in layers and the mechanical properties gradients. The abrupt changes of structure and of properties between core and layer are very important there.

In practice there occur the surfaces which are obtained as a result of applying many techniques, e.g. thermal treatment, thermo-chemical and surface plastic treatments and PVD techniques.

\section{The mechanical properties of surface strengthened materials}

\subsection{The influence of particular technologies of surface hardening on fatigue strength limit}

\subsubsection{The influence of carbonitriding}

The dependence between thickness of hardened layer and fatigue strength limit $\sigma_{-1}$ on specimens in diameter of $15 \mathrm{~mm}$ of steel St3 was investigated. $\sigma_{-1}$ has been determined as a function of layer thickness. Its curve has been shown in Fig. 1. The results show that the applied method of carbonitriding increases the fatigue strength at each thickness of layer. The best result - the increase in $\sigma_{-1}$ up to $25 \%$ - is obtained at the thickness of about $0.65 \mathrm{~mm}$ [2].

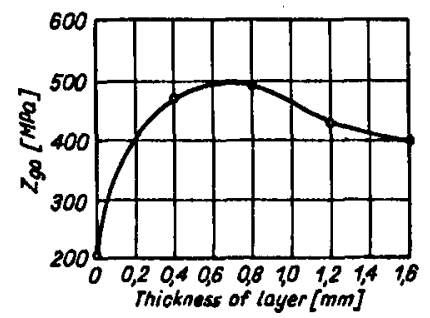

Fig. 1. Relation between fatigue strength and thickness of layer after carbonitriding.

This observation has been confirmed by the results of tests described in paper [2], where the result of increase up to $248 \%$ of fatigue strength has been gained with steel $18 \mathrm{HGT}$, for the layer $0.7 \mathrm{~mm}$ thick. The properties of that steel after carbonitriding and carburizing have been shown in Table I. Smith chart has been shown in Fig. 2. As it can be seen in Table I, it was not possible to determine plastic properties of the steel after carbonitriding and carburizing. Steel 18HGT after these treatments showed features of a brittle material [3], see Fig. 3.

\subsubsection{The influence of nitriding}

The tests with nitrided steels 18HNMA and 38HNMJuA showed connection between $\sigma_{-1}$ and thickness of nitrided layer [2]. It is said in technical literature that the influence of nitriding on the fatigue strength is diversified for different materials and cannot be determined by any general rule. The most diversified influence of nitriding can be observed near a notch. The technology of nitriding can always guarantee the increase in fatigue of nitrided specimens with notch. 


\section{TABLE I}

Strength properties of the steel $18 \mathrm{HGT}$ at various stages of treatment.

\begin{tabular}{|c|c|c|c|}
\hline $\begin{array}{l}\text { Treatment } \\
\text { Properties }\end{array}$ & Normalizing & Carbonitriding & Carburizing \\
\hline$R_{\mathrm{e}}[\mathrm{MPa}]$ & 430 & - & - \\
\hline$R_{\mathrm{m}}[\mathrm{MPa}]$ & 600 & 1303 & 1300 \\
\hline$A_{5}[\%]$ & 30 & - & - \\
\hline$Z[\%]$ & 70 & - & - \\
\hline$R_{\mathrm{gpl}}[\mathrm{MPa}]$ & 823 & - & - \\
\hline$R_{\mathrm{g}}[\mathrm{MPa}]$ & - & 2890 & 2604 \\
\hline$\sigma_{-1}[\mathrm{MPa}]$ & 358 & 887 & 745 \\
\hline Thickness [mm] & - & 0.7 & 1.0 \\
\hline Increase $\sigma_{-1}[\%]$ & 100 & 248 & 208 \\
\hline
\end{tabular}

$R_{\mathrm{e}}$ - yield strength, $A_{5}$ - extension, $R_{\mathrm{gpl}}$ - bending yield strength, $\sigma_{-1}$ - fatigue strength limit, $R_{\mathrm{m}}$ - tensile strength, $Z$ - necking, $R_{\mathrm{g}}$ - bending strength.

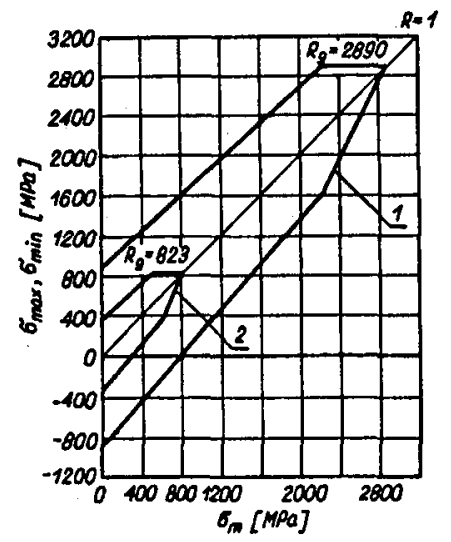

Fig. 2. Dependence of the fatigue strength limit on the average stress of the load cycle, $\sigma_{m}$ (Smith diagram) for the steel 18HGT after: 1 - carbonitriding, 2 - normalizing.

The way of specimens loading is very important; its influence can be characterised by the following figures [2]:

bending increase

tension increase

torsion increase
$\max .850 \%$
$\max .255 \%$
$\max .188 \%$

$$
\begin{aligned}
& \min .110 \% \text {, } \\
& \text { min. } 95 \% \text {, } \\
& \text { min. } 114 \% \text {. }
\end{aligned}
$$

In experiments described in paper [4] the influence of fatigue strength on the steel $40 \mathrm{H}$ and 33H3MF under conditions of bending loads was tested.

The statement of strength features of these kinds of steel has been shown 


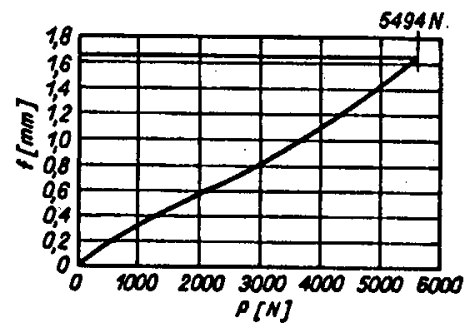

Fig. 3. Diagram of static bending of specimen of the steel $18 \mathrm{HGT}$ after carburizing.

TABLE II

Strength properties of the steels $40 \mathrm{H}, 33 \mathrm{H} 3 \mathrm{MF}$ at various stages of treatment.

\begin{tabular}{l|c|c|c|c}
\hline \multirow{2}{*}{ Properties } & \multicolumn{2}{c|}{$40 \mathrm{H}$} & \multicolumn{2}{c}{ 33H3MF } \\
\cline { 2 - 5 } & Toughening & Nitriding & Toughening & Nitriding \\
\hline$R_{\mathrm{e}}[\mathrm{MPa}]$ & 998 & 993 & 845.3 & - \\
$R_{\mathrm{m}}[\mathrm{MPa}]$ & 1075 & 963 & 937 & 1032 \\
$A_{5}[\%]$ & 15.5 & 10.7 & 19 & - \\
$Z[\%]$ & 59 & 19 & 65 & - \\
$R_{\mathrm{gpl}}[\mathrm{MPa}]$ & 2004 & 1920 & 2018 & 2073 \\
$R_{\mathrm{g}}[\mathrm{MPa}]$ & - & - & - & - \\
$\mathrm{KCU}\left[\mathrm{J} / \mathrm{cm}^{2}\right]$ & 177.5 & 114.4 & 110 & 65 \\
$\sigma_{-1}[\mathrm{MPa}]$ & 530 & 711 & 530 & 597 \\
$\sigma_{-1}[\mathrm{MPa}]$ & & & & \\
$\quad R=0$ & 1765 & 1160 & 1820 & 1030 \\
$R=0.1$ & 2000 & 1240 & 2017 & 1105 \\
Thickness $[\mathrm{mm}](400 \mathrm{HVo}, 5)$ & - & 0.25 & - & 0.40 \\
Increase $\sigma_{-1}[\%]$ & 100 & 134 & 100 & 113 \\
\hline
\end{tabular}

$R_{\mathrm{e}}$ - yield strength, $A_{5}$ - extension, $R_{\mathrm{gpl}}$ - bending yield strength, $\sigma_{-1}-$ fatigue strength limit, $R_{\mathrm{m}}$ - tensile strength, $Z$ - necking, $R_{\mathrm{g}}$ - bending strength, KCU - impact strength.

in Table II. The simplified Smith chart has been shown in Fig. 4. The plastic properties of steel after nitriding are much better than after carburizing and carbonitriding.

\subsubsection{The influence of carburizing}

In papers [2,3] dependence of $\sigma_{-1}$ in function of thickness of carburized layer has been found. When steel 10 was used, the highest increase in $\sigma_{-1}$ for about $176 \%$ was in layer $0.75 \mathrm{~mm}$ thick; for steel 18HNMA the highest increase by $137 \%$ appears at thickness $0.4 \mathrm{~mm}$.

When the notches were on the sample the maximal increase in fatigue strength 


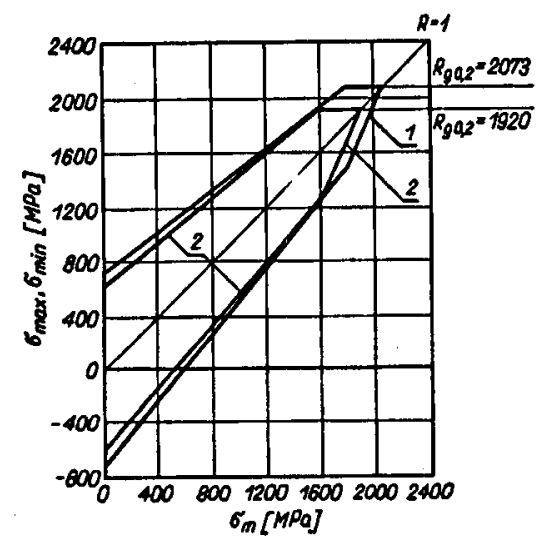

Fig. 4. Simplified Smith diagram for steels after nitriding: $1-$ steel 33H3MF, $2-$ steel $40 \mathrm{H}$.

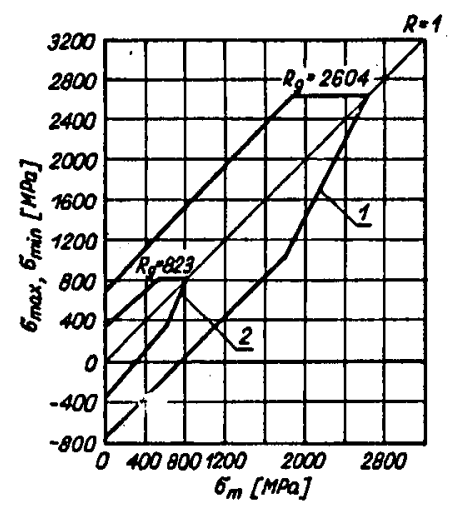

Fig. 5. Simplified Smith diagram for the steel 18HGT after: $1-$ carburizing, $2-$ normalizing.

$350 \%$ and minimal $62 \%$ for low-alloy steel chromium-nickel-molybdenum was gained.

For specimens without notch the maximal increase by $288 \%$ and minimal by $113 \%$ was reached.

The way of loading caused:

$\begin{array}{lll}\text { bending increase } & \max .330 \% & \min .62 \%, \\ \text { torsion increase } & \max .242 \% & \min .83 \% .\end{array}$

The presence of notch has the strongest influence on the fatigue strength of materials with hardened, carburized layer and this influence can be better seen during bending than during torsion.

The results obtained in experiment described in paper [4] are shown in Table I and in Fig. 5, where the simplified Smith chart is presented. The 200\% increase in fatigue strength limit, as compared with not carburized specimens, has been gained. 


\subsubsection{The influence of induction hardening}

During experiment described in paper [5] the fatigue strength of the steel 43 sel was obtained for one-side flat bending at $R=$ const $=0.5 N_{\mathrm{G}}=5 \times 10^{6}$ conditions. The results have been shown in Table III. They show that the highest fatigue strength is at martensite-austenite structure.

TABLE III

Fatigue strength of the steel 43 sel after induction hardening in relation to the structure of surface layer.

\begin{tabular}{|c|c|c|c|c|c|}
\hline \multirow{2}{*}{$\begin{array}{l}\text { No. of } \\
\text { testing }\end{array}$} & \multicolumn{2}{|c|}{ Data of hardening } & \multirow[t]{2}{*}{$\overline{Z_{\mathrm{gj}}}$} & \multicolumn{2}{|c|}{ Microstructures } \\
\hline & $P_{\mathrm{g}}[\mathrm{kW}]$ & $V[\mathrm{~mm} / \mathrm{s}]$ & & tested depth [mm] & type \\
\hline III & & & 820.1 & $\begin{array}{c}\text { near the surface } \\
0.64 \\
0.96 \\
\text { core }\end{array}$ & $\begin{array}{l}\text { martensite+retained austenite } \\
\text { bainite+ferrite } \\
\text { martensite+bainite+ferrite } \\
\text { pearlite+ferrite }\end{array}$ \\
\hline VII & 42 & 7.5 & 754.4 & $\begin{array}{c}\text { near the surface } \\
0.64 \\
\text { core }\end{array}$ & $\begin{array}{l}\text { bainite+martensite } \\
\text { martensite+bainite+ferrite } \\
\text { pearlite+ferrite }\end{array}$ \\
\hline I & 30 & 5 & 754.4 & $\begin{array}{l}\text { near the surface } \\
0.64 \\
\text { core }\end{array}$ & $\begin{array}{l}\text { martensite+bainite }+ \text { ferrite } \\
\text { martensite+bainite }+ \text { ferrite } \\
\text { pearlite+ferrite }\end{array}$ \\
\hline $\begin{array}{l}\text { VI } \\
\text { IV }\end{array}$ & $\begin{array}{l}56 \\
30\end{array}$ & $\begin{array}{l}7.5 \\
2.3\end{array}$ & $\begin{array}{l}687.6 \\
687.6\end{array}$ & $\begin{array}{c}\text { near the surface } \\
0.64 \\
0.96 \\
\text { core } \\
\end{array}$ & $\begin{array}{l}\text { martensite+retained austenite } \\
\text { martensite+bainite } \\
\text { bainite+martensite+ferrite } \\
\text { pearlite+ferrite }\end{array}$ \\
\hline II & 56 & 5 & 587.6 & $\begin{array}{c}\text { near the surface } \\
1.1 \\
1.7 \\
\text { core } \\
\end{array}$ & $\begin{array}{l}\text { coarse grained martensite } \\
\text { bainite+martensite } \\
\text { martensite+bainite+ferrite } \\
\text { pearlite+ferrite }\end{array}$ \\
\hline $\mathrm{V}$ & 42 & 2.3 & 288.4 & $\begin{array}{c}\text { near the surface } \\
1.92 \\
2.56 \\
2.88 \\
\text { core }\end{array}$ & $\begin{array}{l}\text { coarse grained martensite } \\
\text { bainite+ferrite } \\
\text { bainite+martensite } \\
\text { bainite+ferrite } \\
\text { pearlite+ferrite }\end{array}$ \\
\hline
\end{tabular}

\subsubsection{The influence of surface plastic treatment}

The surface plastic treatment has the positive influence on the fatigue strength and the shot peening is the most effective kind of treatment. In Fig. 6 the changes of fatigue strength of the steel 30HGSA after surface plastic treatment are presented [6]. The high increase in fatigue strength limit can be gained by heat treatment or thermo-chemical treatment, followed by shot peening. To exemplify it, the changes of fatigue strength of gears after carburizing followed by shot peening have been shown in Fig. 7 [7]. 


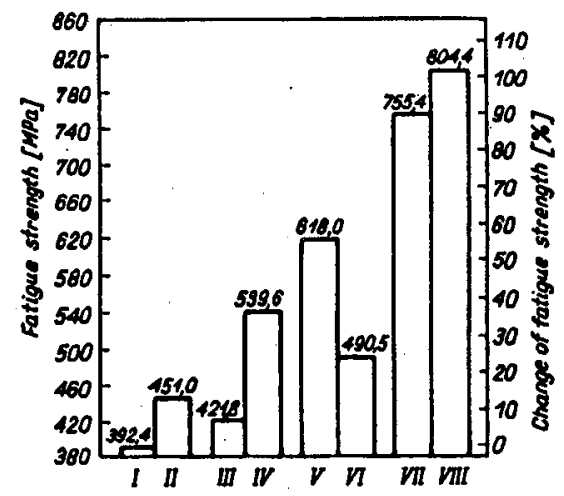

Fig. 6. Histogram of the fatigue strength limits of the steel 30HGSA after various heat and plastic treatments. I - normalizing, II - heat treatment, III - normalizing + shot peening, IV - heat treatment + shot peening, V - normalizing + induction hardening, VI - heat treatment + induction hardening, VII - normalizing + induction hardening + shot peening, VIII - heat treatment + induction hardening + shot peening.

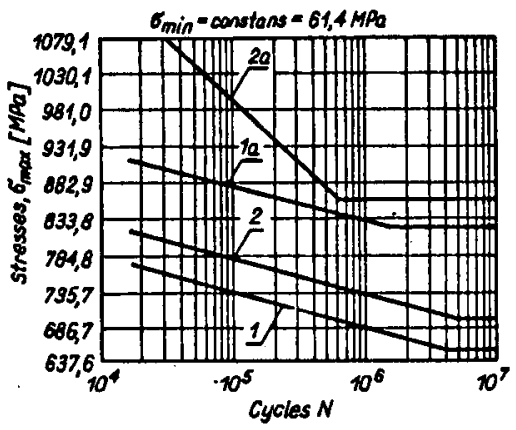

Fig. 7. The Wöhler curve for gear teeth: 1 - hardened $\left(760^{\circ} \mathrm{C}\right), 1 \mathrm{a}-$ hardened and shot peened, $2-$ hardened $\left(890^{\circ} \mathrm{C}\right), 2 \mathrm{a}-$ hardened and shot peened.

\subsection{Fracture}

Dependence of the $K_{\mathrm{Q}}$ (stress intensity coefficient) upon the layer structure has been given in the form of the second-order polynomial as follows:

$$
K_{Q}=125.252+2.360 C-16.335 H-66.485 C^{2}+35.719 H^{2}-1.672 C H,
$$

value of the variance $=352.852$, statistic $t$-Student parameter $t_{\text {anal }}=0.60<t_{\text {crit }}$. The obtained shape of the function shows that there exist some values of the carbon contents and hardness by which the top crack resistance could be achieved.

Inquiries about the position of the maximum of this function by means of Monte Carlo methods brought us the following results:

$$
\begin{aligned}
& K_{\max }=170.230 \mathrm{MN} \mathrm{m}^{-3 / 2}, \\
& C_{\text {opt }}=0.741[\% C] \text { (here } C \text { is the carbon content), }
\end{aligned}
$$




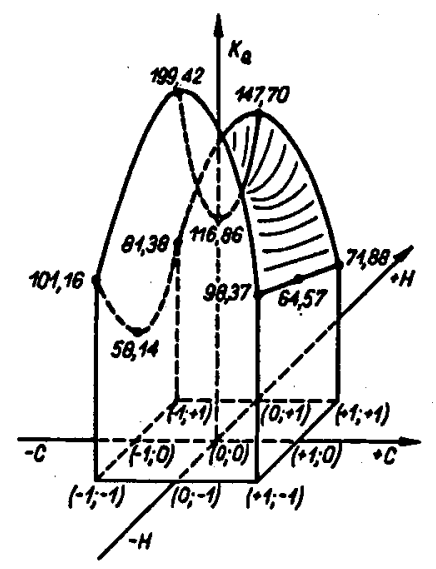

Fig. 8. Plot of the stress intensity coefficient $K_{Q}$ vs. the carbon content $C$ and the hardness $H$.

$$
H_{\text {opt }}=40.459 \text { [HRC]. }
$$

The graphical image of the $K$ function (the answer area) has been presented in Fig. 8 [8].

\section{The influence of surface treatments on tribological properties}

It is obvious that all friction phenomena take place in the specially created surface layer of machine parts. This surface layer has to assure low coefficient of friction, high seizure resistance and to reduce the wear of both co-operating parts. It is known from the professional experience and from the adhesive theory of friction that the less susceptible for seizure two solid bodies are, the higher is their adhesive wear resistance [9].

Considering dependence $\mu=\tau / N$, it is possible to divide friction layers into three groups:

I layers with low shear strength $\tau_{\mathrm{s}}$ and low yield point $R_{\mathrm{e}}$,

II layers with medium shear strength $\tau_{\mathrm{s}}$ and medium yield point $R_{\mathrm{e}}$,

III layers with low shear strength $\tau_{\mathrm{s}}$ and high yield point $R_{\mathrm{e}}$.

At such suggested division of low-friction layers it is necessary to remember that shear strength $\tau_{\mathrm{s}}$ means the shear strength of contact layer of two elementary roughnesses of the surfaces, which have the thickness of tens atomic layers. Moreover, it is necessary to understand that shear strength in the whole volume of the layer strongly depends on the plastic yield of the layer itself. The true surface of contact $A$ and, as a result, the total friction force $T=A \tau_{\mathrm{s}}$ depend on the plastic point of the layer.

When analysing the properties of low-friction layer in association with friction it is necessary to take under consideration its tendency to create weak or strong adhesive connections. If shear strength of adhesive force is higher than the volume shear strength of the whole layer (and it happens very often) then 
Tribological properties of steels

\begin{tabular}{|c|c|c|c|c|c|}
\hline & & & Fric & on at constant pre & ure \\
\hline Steel & $\begin{array}{l}\text { Type of } \\
\text { thermo-chemical } \\
\text { treatment }\end{array}$ & $\begin{array}{l}\text { Loading } \\
F[\text { daN] }\end{array}$ & $\begin{array}{c}\text { Total } \\
\text { volumetric wear } \\
Z_{v}\left[\times 10^{-3} \mathrm{~mm}^{2}\right]\end{array}$ & $\begin{array}{c}\text { Wear } \\
\text { intensity } I_{v} \\
{\left[\times 10^{-6} \mathrm{~mm}^{3} / \mathrm{m}\right]}\end{array}$ & $\begin{array}{c}\text { Wear } \\
\text { resistance } K_{v} \\
{\left[\times 10^{3} \mathrm{~m} / \mathrm{mm}^{3}\right]}\end{array}$ \\
\hline 1 & 2 & 3 & 4 & 5 & 6 \\
\hline 15 & & $\begin{array}{c}40 \\
85 \\
155\end{array}$ & $\begin{array}{c}43.7 \\
245.5 \\
394.7\end{array}$ & $\begin{array}{c}5.52 \\
31.01 \\
49.85\end{array}$ & $\begin{array}{c}181.16 \\
32.25 \\
20.06\end{array}$ \\
\hline $18 \mathrm{HGT}$ & Carburizing & $\begin{array}{c}40 \\
85 \\
155\end{array}$ & $\begin{array}{c}32.7 \\
133.1 \\
344.7^{a} \\
\end{array}$ & $\begin{array}{c}4.13 \\
16.81 \\
43.54 \\
\end{array}$ & $\begin{array}{c}242.13 \\
59.49 \\
22.97\end{array}$ \\
\hline $19 \mathrm{HM}$ & & $\begin{array}{c}40 \\
85 \\
155 \\
\end{array}$ & $\begin{array}{c}44.5 \\
141.5 \\
268.2^{a} \\
\end{array}$ & \begin{tabular}{c|}
5.62 \\
17.87 \\
33.88 \\
\end{tabular} & $\begin{array}{c}177.94 \\
55.06 \\
29.52 \\
\end{array}$ \\
\hline 45 & & $\begin{array}{c}40 \\
85 \\
155\end{array}$ & $\begin{array}{l}128.9 \\
236.0 \\
535.9\end{array}$ & $\begin{array}{l}16.28 \\
29.81 \\
67.43\end{array}$ & $\begin{array}{l}61.43 \\
33.55 \\
14.83\end{array}$ \\
\hline 65 & & $\begin{array}{c}40 \\
85 \\
155\end{array}$ & $\begin{array}{l}278.1 \\
278.1 \\
473.2\end{array}$ & $\begin{array}{l}35.13 \\
35.13 \\
59.77\end{array}$ & $\begin{array}{l}28.47 \\
28.47 \\
16.73\end{array}$ \\
\hline 18HGT & & $\begin{array}{c}40 \\
85 \\
155\end{array}$ & $\begin{array}{l}109.3 \\
117.0 \\
229.8\end{array}$ & $\begin{array}{l}13.81 \\
14.78 \\
29.03\end{array}$ & $\begin{array}{l}72.41 \\
67.66 \\
34.44\end{array}$ \\
\hline $40 \mathrm{HM}$ & Nitriding & $\begin{array}{r}40 \\
85 \\
155\end{array}$ & $\begin{array}{l}137.1 \\
137.1 \\
212.2\end{array}$ & $\begin{array}{l}17.32 \\
17.32 \\
26.80\end{array}$ & $\begin{array}{l}57.74 \\
57.74 \\
37.31\end{array}$ \\
\hline WCL & . & $\begin{array}{c}40 \\
85 \\
155 \\
\end{array}$ & $\begin{array}{c}37.8 \\
62.9 \\
115.1\end{array}$ & $\begin{array}{c}4.77 \\
7.94 \\
14.54\end{array}$ & $\begin{array}{c}209.64 \\
125.94 \\
68.78\end{array}$ \\
\hline 33НЗМF & & $\begin{array}{c}40 \\
85 \\
155 \\
\end{array}$ & $\begin{array}{c}98.7 \\
232.8 \\
226.7\end{array}$ & $\begin{array}{l}1<.47 \\
29.41 \\
28.63\end{array}$ & $\begin{array}{l}80.19 \\
34.00 \\
34.93\end{array}$ \\
\hline $36 \mathrm{H} 3 \mathrm{M}$ & & $\begin{array}{c}40 \\
85 \\
155\end{array}$ & $\begin{array}{l}122.7 \\
159.7 \\
333.3\end{array}$ & $\begin{array}{l}15.50 \\
20.17 \\
42.10\end{array}$ & $\begin{array}{l}64.52 \\
49.58 \\
23.76\end{array}$ \\
\hline $38 \mathrm{HMJ}$ & & $\begin{array}{c}40 \\
85 \\
155\end{array}$ & $\begin{array}{c}29.4 \\
157.3 \\
206.4\end{array}$ & $\begin{array}{c}3.71 \\
19.87 \\
26.07\end{array}$ & $\begin{array}{c}269.54 \\
50.32 \\
38.36\end{array}$ \\
\hline
\end{tabular}

${ }^{a}$ Seizure during testing has appeared.

the shearing of connection will occur not at the surface of contact but under the surface of the low-friction layer.

The following layers belong to the group of the low shear strength:

1. graphite layers;

2. molybdenum disulphide, wolfram disulphide or hexagonal boron nitride layers; 
TABLE IV

after thermo-chemical treatment.

\begin{tabular}{|c|c|c|c|c|}
\hline & \multicolumn{4}{|c|}{ Friction at increasing pressure } \\
\hline $\begin{array}{c}\text { Medium } \\
\text { friction } \\
\text { coefficient } y_{s \mathrm{~s}}\end{array}$ & $\begin{array}{c}\text { Total } \\
\text { volumetric } \\
\text { wear } Z_{v}\left[\times 10^{-3} \mathrm{~mm}^{3}\right]\end{array}$ & $\begin{array}{c}\text { Critical force } \\
\text { (seizure) } \\
P_{\mathrm{kr}}[\mathrm{daN}]\end{array}$ & 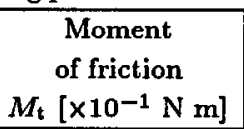 & $\begin{array}{l}\text { Instantaneous } \\
\text { coefficient of } \\
\text { friction } \mu_{\mathrm{ch}}\end{array}$ \\
\hline 7 & 8 & 9 & 10 & 11 \\
\hline $\begin{array}{l}0.086 \\
0.090 \\
0.088\end{array}$ & 539.3 & 35 & 50 & 0.815 \\
\hline $\begin{array}{c}0.080 \\
0.128 \\
-\end{array}$ & 215.1 & 27 & 50 & 1.058 \\
\hline $\begin{array}{c}0.081 \\
0.088 \\
-\end{array}$ & 150.3 & 25 & 50 & 1.143 \\
\hline $\begin{array}{l}0.082 \\
0.080 \\
0.095 \\
\end{array}$ & 63.1 & 75 & 50 & 0.389 \\
\hline $\begin{array}{l}0.085 \\
0.096 \\
0.094\end{array}$ & 167.1 & 45 & 30 & 0.384 \\
\hline $\begin{array}{l}0.092 \\
0.095 \\
0.087\end{array}$ & 91.8 & 55 & 50 & 0.519 \\
\hline $\begin{array}{l}0.092 \\
0.052 \\
0.088\end{array}$ & 76.6 & 30 & 50 & 0.952 \\
\hline $\begin{array}{l}0.091 \\
0.093 \\
0.090 \\
\end{array}$ & 55.3 & 65 & 50 & 0.434 \\
\hline $\begin{array}{l}0.102 \\
0.085 \\
0.101 \\
\end{array}$ & 103.5 & 55 & 50 & 0.519 \\
\hline $\begin{array}{l}0.105 \\
0.108 \\
0.109\end{array}$ & 167.9 & 65 & 50 & 0.434 \\
\hline $\begin{array}{l}0.067 \\
0.097 \\
0.110\end{array}$ & 220.1 & 140 & 145 & 0.591 \\
\hline
\end{tabular}

3. metallic layers or plastic layers in which by means of special technology the "inclusions" of graphite, molybdenum disulphide or wolfram disulphide have been created.

To the second group of low-friction layers there belong layers generated from pure metals: indium, tin, silver, copper, and nickel, subsequently.

To the third group there belong the layers with high plastic point $R_{\mathrm{e}}$ and 
low shear strength $\tau_{\mathrm{s}}$ of contact surface. These are the layers of titanium carbide (TiC), titanium nitride (TiN), silicon carbide (SiC), boron nitride (BN) of the diamond, amorphous carbon or diamond-like structure. These layers belong to the low-friction super-hard layers.

Surface hardening, thermo-chemical treatments, surface plastic treatment and modern treatment by ion implantation are generally known and used to improve tribological properties of materials.

The tribological properties of constructional and tool steel after surface treatment, most often used in industry, have been presented in Table IV.

Tribological tests were done by means of machine A-135 at the following preset parameters:

- loading: $40,85,155$ daN,

- friction velocity: $0.36 \mathrm{~m} \mathrm{~s}^{-1}$,

- path of friction: $7517 \mathrm{~m}$,

- drip-feed lubrication: 30 drops/min, with oil Lux 10.

During seizure resistance test the increasing loading at value 5 daN every $30 \mathrm{~s}$, friction technologically dry, was applied [10].

\section{Designing of machine parts, on taking into account the properties of surface layers}

Contemporary methods of designing machine parts consider their mechanical properties from the point of view of their static parameters, such as their tensile strength $R_{\mathrm{m}}$, plastic point $R_{\mathrm{e}}$, modules of elasticity $E$, Poisson's ratio $\nu$, hardness $H$, or their dynamic parameters such as limit of fatigue strength $\delta_{-1}$, stress intensity factor $K_{\text {IC }}$ [11-13].

The applied methods of calculation of hardness do not take into account, to a sufficient degree, the presence of surface layer which appears in the modern technological process of production.

The existing types of surface layer are difficult to model for calculations. Because of this it is profitable to suggest a model which describes the surface layer by means of parameters useful for mechanical calculations.

\subsection{Characteristic of functional properties of surface layers}

In Fig. 9 the curve $3(H, \sigma)$ shows the universal characteristic of functional properties in cross-section of the designed part of a machine. The curve can present the distribution of:

- fatigue strength limit,

- contact fatigue strength limit,

- wear resistance.

An assumption was made that the distribution of functional property in a cross-section of specimen (fatigue strength or wear resistance) is a function of hardness and residual stresses [11]. It could be seen that for any point at the section the value of hardness $H$ and residual stresses could be determined. It means that for any known value of the distribution of external loads it is possible to determine the place of destruction and other basic data for technologists: hardness, thickness of layer, state of residual stresses (which allow to create the layer wanted). 


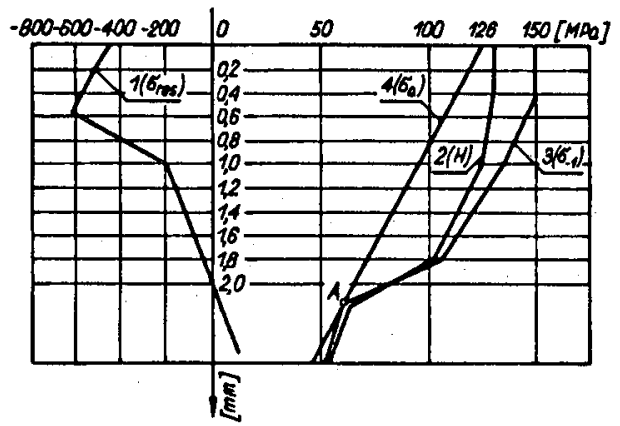

Fig. 9. Characteristic of functional properties of surface layers. Fatigue strength and external loading in crankshaft neck after induction hardening as a function of the surface layer thickness: 1 - distribution of residual stresses, 2 - distribution of fatigue strength value as a function of hardness, 3 - distribution of fatigue strength value as a function of hardness and residual stresses, $4-$ distribution of external loading. $A-$ point of destruction.

\subsection{Designing of surface layers by using theory of plasticity and elasticity}

The initial features of a layer are described by the value of modulus of elasticity, hardness, stress field and residual stresses field. As a result of analysis the field of plastic strains and the field of residual stresses can be received. The FEM (finite element method) calculated changes of state of surface layers are here caused by elasto-plastic strains.

There are, however, two serious difficulties to use the theory of elasto-plastic strains and computer analysis. The first difficulty is how to determine the local properties $\left(R_{\mathrm{e}}, E\right)$, the second - how to formulate physical and mathematical model of surface layer, which could be used in computer analysis.

For a full description of properties of surface layers the occurrence of great plastic strains, mechanical anisotropy and structural changes must be considered.

Now only the simplified models can be offered, on assuming:

a) mechanical anisotropy at small strains, or

b) isotropic plasticity at big strains [12].

The models allow to analyse the state of stresses and strains in surface layer, using the method of finite elements (Fig. 10).

In paper [13] the fields of stresses in axial-semitropical, statically loaded elements were determined. The tested element was divided into $N$ coaxial cylinders. Each of those cylinders was assigned with the value of residual stresses, modules of elasticity, plastic point and $E$ and $X$ values after exceeding the plasticity point. For such model the solution of Lame was used.

When the boundary conditions for these methods are included, the system of equation is obtained which allows to evaluate the shift of strain and stress at each of $N$ points. The described method allows us to evaluate the dependence of the stresses on the load, residual stresses and the state of strains, as a discrete 


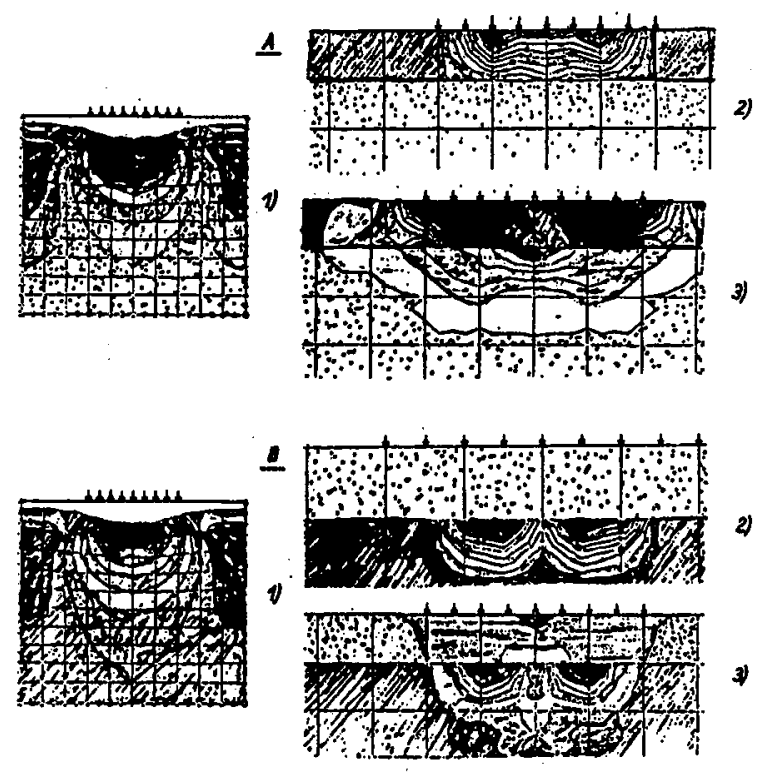

Fig. 10. MES calculated fields of plastic strains and stresses in surface layers and core: (A) strains of soft layer over hard core, (B) strains of hard layer over soft core, 1 effective stresses, 2 - plastic strains, 3 - residual stresses.

function of the radius and axial strains and of the loading force, as a function of the strain for any pre-set run of initial data.

\section{References}

[1] Umacnianie kompozytowych warstw wierzchnich części maszyn, Eds. M. Marciniak, A. Nakonieczny, K. Skalski, Instytut Technologii Mechanicznej, Politechnika Warszawska, Warszawa 1993 (in Polish).

[2] A. Buch, Zagadnienia wytrzymatości zmęczeniowej, PWN, Warszawa 1964 (in Polish).

[3] A. Nakonieczny, in: XXV Seminarium Instytutu Mechaniki Precyzyjnej, Wyd. Inst. Mech. Precyzyjnej, Warszawa 1985, p. 21 (in Polish).

[4] A. Nakonieczny, MAT-TEC91, Ed. A. Niku-Lari, IITT-International, Gournay-sur-Marne, p. 119.

[5] A. Nakonieczny, Metaloznawstwo i Obróbka Cieplna 41, 14 (1979) (in Polish).

[6] A. Nakonieczny, in: XXIV Seminarium Instytutu Mechaniki Precyzyjnej, Wyd. Inst. Mech. Precyzyjnej, Warszawa 1984, p. 49 (in Polish).

[7] A. Nakonieczny, E. Lamprecht, Eksploatacja i dozór 7, 11 (1980) (in Polish).

[8] A. Nakonieczny, W. Amanowicz, Works of Institute of Precision Mechanics No. 103.00.0002, Warszawa 1980.

[9] Z. Haś, J. Gramsz, W. Jarosz, Wear 64, 333 (1980).

[10] J. Senatorski, in: XXIV Seminarium Instytutu Mechaniki Precyzyjnej, Wyd. Inst. Mech. Precyzyjnej, Warszawa 1984, p. 53 (in Polish). 
[11] A. Nakonieczny, in: XXVIII Seminarium nt. Wybrane zagadnienia inżynierii powierzchni, Wyd. Inst. Mech. Precyzyjnej, Warszawa 1994, p. 5 (in Polish) .

[12] W. Gambin, A. Nakonieczny, K. Skalski, Mechanika teoretyczna i stosowana 4, (1993) (in Polish).

[13] Z. Hanzel-Powierża, G. Starzyński, Przeglqd Mechaniczny 18, 32 (1987) (in Polish). 